\title{
Optimal design and planning of biodiesel supply chain with land competition
}

\author{
F. Andersen ${ }^{a}$, F. Iturmendi ${ }^{a}$, S. Espinosa ${ }^{\text {b }}$, M.S. Diaz ${ }^{\mathrm{a}, *}$ \\ a Planta Piloto de Ingeniería Química, PLAPIQUI, Universidad Nacional del Sur, CONICET. Camino La Carrindanga km 7, 8000 Bahía Blanca, Argentina \\ b Departamento de Ingeniería Química y Ambiental, Universidad Técnica Federico Santa María, Avda. España 1680, Valparaíso, Chile
}

\section{A R T I C L E I N F O}

\section{Article history:}

Received 6 April 2012

Received in revised form 28 June 2012

Accepted 29 June 2012

Available online 8 July 2012

\section{Keywords:}

Supply chain

Biodiesel

MILP

Optimal planning

Jatropha

\begin{abstract}
A B S T R A C T
In this work we propose an MILP multiperiod formulation for the optimal design and planning of the Argentinean biodiesel supply chain, considering land competition and alternative raw materials. The country is divided into twenty three regions, each one including existing crops, oil and biodiesel plants and potential ones. The model includes intermediate and final products, i.e., seed, flour, pellets and expellers, oil, pure and blending biodiesel and glycerol. Crop fields, storage and production plants, as well as distribution centers for internal and external markets are also represented. We consider the possibility of sowing energetic crops, such as Jatropha curcas, in marginal areas. The time horizon is of seven years, divided into 84 periods. The mathematical model has been implemented in GAMS providing a powerful decision-making tool that can be applied to other regions or countries by adjusting specific data.
\end{abstract}

(c) 2012 Elsevier Ltd. All rights reserved.

\section{Introduction}

Biodiesel production is currently been explored throughout the world to assess economical and environmental profits of replacing increasing percentages of fossil-based diesel by biodiesel. The analysis includes the entire production chain, from land availability, raw materials transformation to intermediate and final products and storage and distribution to internal and external markets. It results in a large network combining several stages with different options at each stage, from alternative biomass crops to the location of product storage and conversion facilities, means of transport and flows of biomass and products among regions. Supply chain model design and optimization strategies have been reported in the literature in the last years. Different aspects of the supply chain such as network configuration, design and operation under uncertainty, planning decisions and management of the entire supply chain, have been analyzed by several authors (Dunnett, Adjiman, \& Shah, 2008; Guillen-Gosálbez \& Grossmann, 2010; Guillén-Gosálbez, Mele, \& Grossmann, 2009, 2010; Papageorgiou, Rotstein, \& Shah, 2001; Schulz, Diaz, \& Bandoni, 2005; Shah, 2005; Shapiro, 2004; You \& Grossmann, 2007, 2010). A few authors have addressed process synthesis and supply chain optimization for first generation biofuels, reporting important savings in energy consumption (Karuppiah et al., 2008; Kostin, Guillén-Gosálbez, Mele, Bagajewicz, \& Jiménez, 2010). The optimal design of biomass supply chain networks for biofuels has been addressed by Dunnett

\footnotetext{
* Corresponding author.

E-mail address: sdiaz@plapiqui.edu.ar (M.S. Diaz).
}

et al. (2008) to produce bioethanol from lignocellulosic biomass feedstocks. They propose a spatially explicit model combining production and logistics data for the United Kingdom, maximizing net profit. Zamboni, Bezzo, and Shah $(2009,2009 b)$ propose a spatially explicit model for the design of the Italian corn-based ethanol supply chain as a Mixed Integer Linear programming (MILP) with an economic objective function. In the second part of this work, the model is extended by including environmental concerns within the optimization framework. Bioethanol production from lignocellulosic biomass has been also addressed by Slade, Bauen, and Shah (2009), mainly focused on investigating the commercial viability in Europe. Mele, Kostin, Guillén-Gosálbez, and Jiménez (2010) formulate a multi-objective model for the sugarcane/ethanol supply chain optimization, which simultaneously minimizes costs and environmental impact at each stage of the production chain. The design problem is formulated as a generic three-echelon supply chain (production-storage-markets) for the sugarcane industry in Argentina. The authors analyze ethanol supply chain including the purchase of sugarcane as raw material, production, storage, transportation and distribution of final products. More recently, Akgul, Zamboni, Bezzo, Shah, and Papageorgiou (2011) propose mixed integer linear programming (MILP) models to optimize the complete corn-based bioethanol supply chain on a case study in Northern Italy. Andersen, Iturmendi, Espinosa, and Diaz (2010, 2012) have proposed MILP models of increasing complexity for the biodiesel supply chain, taking into account the use of alternative raw materials.

In this work we address optimal design and planning of the biodiesel supply chain in Argentina, based on soybean, sunflower and energy crops (Jatropha curcas), including land competition for 


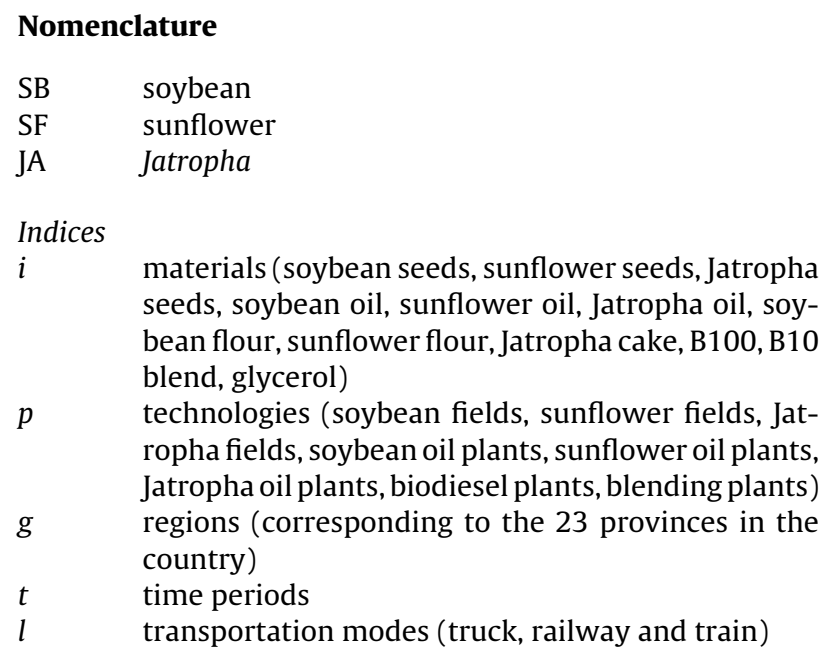

Sets

$M P(i, p) \quad$ set of main product $i$ in production technology $p$

$P P(i, p) \quad$ set of products $i$ produced by production technology $p$

PRM $(i, p)$ set of products $i$ used as raw materials in production technology $p$

$S E E D(i)$ set of raw materials that require re-seeding yearly

TREE $(i)$ set of raw materials that remain cultivated up to the end of their life cycle

PORTS $(g)$ set of regions that have ports

\section{Parameters}

$\eta_{\text {ipgt }} \quad$ crops yield ( $\mathrm{t} /$ hectare) of product $i$ through production technology $p$ in region $g$ and time period $t$

$\mu_{i p} \quad$ mass balance coefficient of product $i$ and production technology $p$ (t product $i / \mathrm{t}$ main product)

$A A_{g t} \quad$ available land area to be sown in region $g$ and time period $t$ (ha)

Aseed $_{i, g}$ upper bound on areas dedicated to soybean and sunflower crops in region $g$ (ha)

$A_{J A, g, t} \quad$ upper bound on areas dedicated to Jatropha crops in region $g$ and time period $t$ (ha)

Aunusd $_{g}$ total unused suitable land in region $g$ (ha)

Gs coefficient related to a gradual increase in available area for crops $(G s=0.03)$

$F J A_{g} \quad$ fraction of land corresponding to marginal zones

$\lambda_{g t} \quad$ factor representing Jatropha evolution as new product in markets

MinR parameter related to crop rotation $(\operatorname{MinR}=0.75)$

$\alpha(p) \quad$ installed capacity factor $(\alpha(p) \leq 1)$

$U B Q P p$ upper bound on expansion capacity of production technology $p$

$L B Q P_{p} \quad$ lower bound on expansion capacity of production technology $p$

$U B Q S_{i} \quad$ upper bound on expansion storage capacity of product $i$

$L B Q S_{i} \quad$ lower bound on expansion storage capacity of product $i$

$T O R_{i} \quad$ turnover ratio of product $i$ from warehouses

$T_{O R P_{i}} \quad$ turnover ratio of product $i$ from ports

$D D M_{\text {igt }}$ local demand for product $i$ in region $g$ and time period $t$ ( $\mathrm{t}$ of product $i$ )

Dsat $_{\text {igt }}$ minimum desired satisfaction level

$G E$ time projection for requirement in international markets $(\mathrm{GE}=3 \%)$
$E M A X_{i} \quad$ maximum exports level of product $i$

$E M I N_{i} \quad$ minimum exports level of product $i$

$\varepsilon$ minimum percentage of total transportation by truck

$T R \quad$ fixed tax rate

WCF working capital factor

$S V F \quad$ salvage value factor

$E P R_{i} \quad$ price of product $i$ in external markets

$D P R_{i} \quad$ price of product $i$ in domestic markets

$I P P R_{i} \quad$ importation cost for product $i$

$U P C_{p g t}$ production cost for technology $p$ in region $g$ and time period $t$

$U_{S C}$ storage cost for product $i$ in region $g$ and time period $t$

$F_{i l} \quad$ unitary cost of each transportation mode $l$ for product $i$

$D T_{g g^{\prime}} \quad$ distance between regions $g$ and $g^{\prime}$

$P_{R B T_{t}}$ profit before tax in time period $t$

LENPty Number of periods in year ty

Qup $_{\text {lg }} \quad$ upper bound on quantity transported by transportation mode $l$ from region $g$

$\mathrm{Qlo}_{\lg } \quad$ lower bound on quantity transported by transportation mode $l$ from region $g$

$F C I P_{p} \quad$ fixed plant cost for production technology $p$

FCIS $_{i} \quad$ fixed storage cost for production technology $p$

$V C I P_{p} \quad$ variable plant cost for production technology $p$

$V C I S_{i} \quad$ variable storage cost for production technology $p$

$C S P_{\text {igt }}$ port storage capacity for each product $i$ in region $g$ and time period $t$

Variables

$A S L_{i g t}$ average warehouse storage level for product $i$ in region $g$ and time period $t$ ( $t$ of product $i$ )

$A S L P_{\text {igt }}$ average port storage level for product $i$ in region $g$ and time period $t$ ( $\mathrm{t}$ of product $i$ )

$S W_{i g t} \quad$ inventory level of material $i$ in region $g$ and time period $t$

$P R_{\text {ipgt }} \quad$ production of product $i$ through production technology $p$ in region $g$ and time period $t$

$I P_{\text {igt }} \quad$ purchases (imports) of material $i$ in region $g$ and time period $t$

$Q_{i l g g ' t}$ mass transported of material $i$ in transport mode from region $g$ to regions $g^{\prime}$ in the time period $t$

$D P_{\text {igt }} \quad$ total sales of product $i$ in region $g$ and time period $t$

$D D_{\text {igt }} \quad$ domestic sales of product $i$ in region $g$ and time period $t$

$D E_{\text {igt }} \quad$ exports of product $i$ in region $g$ and time period $t$

$D E P_{t} \quad$ depreciation in time period $t$

MV market value of investments at the end of the time horizon

$R E V_{t} \quad$ incomes in time period $t$

FOC $_{t}$ facility operating cost in time period $t$

TOC $_{t}$ transportation cost in time period $t$

$A_{\text {igt }} \quad$ sown surface area of material $i$ in region $g$ and time period $t$ (ha)

$C P_{\text {pgt }} \quad$ plant capacity for each production technology $p$ and region $g$ in time period $t$

$C E P_{\text {pgt }}$ plant capacity expansion for each production technology $p$ and region $g$ in time period $t$

$N P_{p g t} \quad$ number of new plants of technology $p$ to be installed in region $g$ and time period $t$ (integer variable)

$C S_{\text {igt }} \quad$ warehouse storage capacity for each product $i$ in region $g$ and time period $t$ 


\begin{tabular}{|c|c|}
\hline$C E S_{\text {igt }}$ & $\begin{array}{l}\text { warehouse storage capacity expansion for product } i \\
\text { in region } g \text { and time period } t\end{array}$ \\
\hline$N S_{\text {igt }}$ & $\begin{array}{l}\text { number of new warehouses for storage product } i \text { to } \\
\text { be installed in region } g \text { and time period } t \text { (integer } \\
\text { variable) }\end{array}$ \\
\hline$Y_{\text {ilgg't } t}$ & $\begin{array}{l}\text { binary variable for each product } i \text { transported } \\
\text { by transportation technology } l \text { between different } \\
\text { regions } g \text { and } g^{\prime} \text { in time period } t \text { that is transported }\end{array}$ \\
\hline$X_{\text {igg't }}$ & $\begin{array}{l}\text { binary variable for annual contract transportation } \\
\text { by shipping of product } i \text { between regions } g \text { and } g^{\prime}\end{array}$ \\
\hline NPV & Net Present Value \\
\hline$F C I_{t+1}$ & capital investment in time period $t+1$ \\
\hline$C F_{t}$ & cash flow in time period $t$ \\
\hline$P R B T_{t}$ & profit before taxes in time period $t$ \\
\hline$P C I_{p g t}$ & $\begin{array}{l}\text { capital investment in new plants in region } g \text { and } \\
\text { time period } t\end{array}$ \\
\hline$S C I_{\text {igt }}$ & $\begin{array}{l}\text { capital investment in warehouses in region } g \text { and } \\
\text { time period } t\end{array}$ \\
\hline
\end{tabular}

seed production. The resulting MILP model takes into account production, storage and transportation for seeds, oil, flour, biodiesel, glycerol and biodiesel blends.

\section{Biodiesel production in Argentina: current situation and potential conditions}

During the last years, Argentina has become the first biodiesel world exporter and the fourth world biodiesel producer (CARBIO, 2010; Energy Market, 2010; Molina, 2010a). Current biodiesel production is mainly based on soybean oil. Argentina is the world's third largest soybean producer and global leader as soybean oil and meal supplier (World Oil, 2010). With the lowest world soybean production costs and one of the most efficient oil-crushing industries in the world (Andreani, 2008; Molina, 2007), Argentina has a crushing capacity of approximately 60 million tons per year and exports over 90\% - close to 7.5 million tons - of its annual oil production (SAGPyA, 2010). The main soybean region is concentrated within a radius of $200 \mathrm{~km}$ of Rosario, a port city in Santa Fe Province, which also accounts for around 80 percent of Argentinean biodiesel production capacity (Ibañez, 2008; SAGPyA, 2010). Rosario is one of the main fluvial ports on Paraná river that runs through Brazil, Paraguay and Argentina, constituting an important waterway linking inland cities in Argentina and Paraguay to the ocean and providing deep-water ports within an area that has a concentration of $75 \%$ of gross domestic product of Argentina. The fluvial transport through the Paraguay-Paraná waterway along $3400 \mathrm{~km}$, involves 5 countries (Argentina, Brasil, Uruguay, Paraguay and Bolivia) and it constitutes an economical way to transport the equivalent of 80 trucks per barge.

Current regulations in Argentina require blends of $5 \%$ ethanol in gasoline (Biofuels Law 26093, 2006) and 5\% biodiesel blends in gasoil. This goal involves about 800,000 tons of biodiesel for local demand and about 1,300,000-1,600,000 tons for international demand (Oil World, 2010; SAGPyA, 2010). Furthermore, in July 2010 biodiesel blends regulation was increased to $10 \%$ (B10) to reduce diesel imports (Molina, 2010b, 2010c) and there is the possibility to increase to B20 in 2015 . There are currently 15 companies producing pure biodiesel (B100) for internal demand and the 4 companies operating in Argentina - YPF, Shell, Exxon and Petrobras - provide nine blending points distributed along the country in five provinces (Buenos Aires, Santa Fe, Salta, Mendoza and Neuquén) (CADER, 2010).

Even though Argentina has an important potential to satisfy increasing biodiesel world demand, further analysis is required to decide whether to keep on producing biodiesel from traditional crops like soybean, sunflower and rapeseed, or gradually change to alternative crops like cartamo, Jatropha and algae, thus reducing land competition between energy sources and food. Dam, Faaij, Hilbert, Petruzzi, and Turkenburg (2009) have analyzed the economic feasibility of extending the large-scale soybean production to nontraditional regions in Argentina, by estimating the potential supply of biomass when food and biofuel demand are met, under different scenarios to 2030. These authors recommend the extension of soybean production to La Pampa province, improving railway logistics to make existing agricultural areas economically attractive for bioenergy production. However, they point out the economic risk associated to the existence of large areas of land in the country dedicated to soybean production with strong dependence on world market. The National Institute of Agricultural Technology (INTA) reports a positive energetic balance for the agricultural phase in biodiesel production from soybean (Donato, Huerga, \& Hilbert, 2008). Nevertheless, Iermanó and Sarandón (2009) include industrial processing of raw material into the analysis and determine that the energetic balance is positive for sunflower but not for soybean-based biodiesel production. Furthermore, 90\% of current biodiesel production in Argentina is based on soybean crops (SAGPyA, 2010) and most of soybean seeds are produced through monocropping (CADER, 2010). The lack of crop rotation has negative effects on soil, biodiversity and farmers independence from market prices (Lamers, McCormick, \& Hilbert, 2008; Lamers, 2006; Pengue, 2005). For this reason, alternative crops like cartamo and Jatropha are been explored in different regions of Argentina, especially in areas that are not appropriate for food crops (SAGPyA, 2006). Therefore, in the present work, biodiesel supply chain from Jatropha is also considered in order to estimate future development to gradually replace or complement soybean oil as raw material for biodiesel production.

Among 186 species of Jatropha, the curcas specie is the most appropriate for biodiesel production. J. curcas does not require fertile soil and it is adequate for preventing soil erosion and desertification. Encouraging experimental results for biodiesel production have been recently reported (Carballo, Flores, \& Hilbert, 2009). The plant requires at least an average annual precipitation of $600 \mathrm{~mm}$ to thrive but it is drought and pest resilient. Jatropha yield increases during the first five years of its life cycle. A typical annual yield is about 7 tons of seeds and between 2.2 and 2.7 tons of oil per hectare. Jatropha trees are productive for up to 30-40 years. Jatropha seeds have up to $40 \%$ oil content (as compared to $18 \%$ oil content in soybean seeds) and $70-80 \%$ can be extracted by cold pressing, increasing to $90 \%$ if kernel pretreatments are applied (Achten et al., 2008). Additionally, the residual seedcake - Jatropha flour - can be composted and used as high-grade nitrogen rich product for land remediation.

There are large field surfaces that are not appropriate for traditional crops, but that can be potentially suitable for Jatropha cultivation. J. curcas, macrocarpa and hieronymi species have been selected as potential biodiesel sources in Argentina (Casotti, 2006a; Casotti \& Font, 2006b; Falasca \& Ulberich, 2008; Font, 2003). The National Institute of Agricultural Technology (INTA) is promoting studies of these native plants (PNEG1412, 2006), with promising results in Santiago del Estero, Catamarca, San Juan, Formosa and La Rioja provinces. Three national companies (Carlos Casado, Celulosa Argentina and Patagonia Bioenergia) will begin biodiesel production based on Jatropha oil (Rozemberg, Saslavsky, \& Svarzman, 2009). 


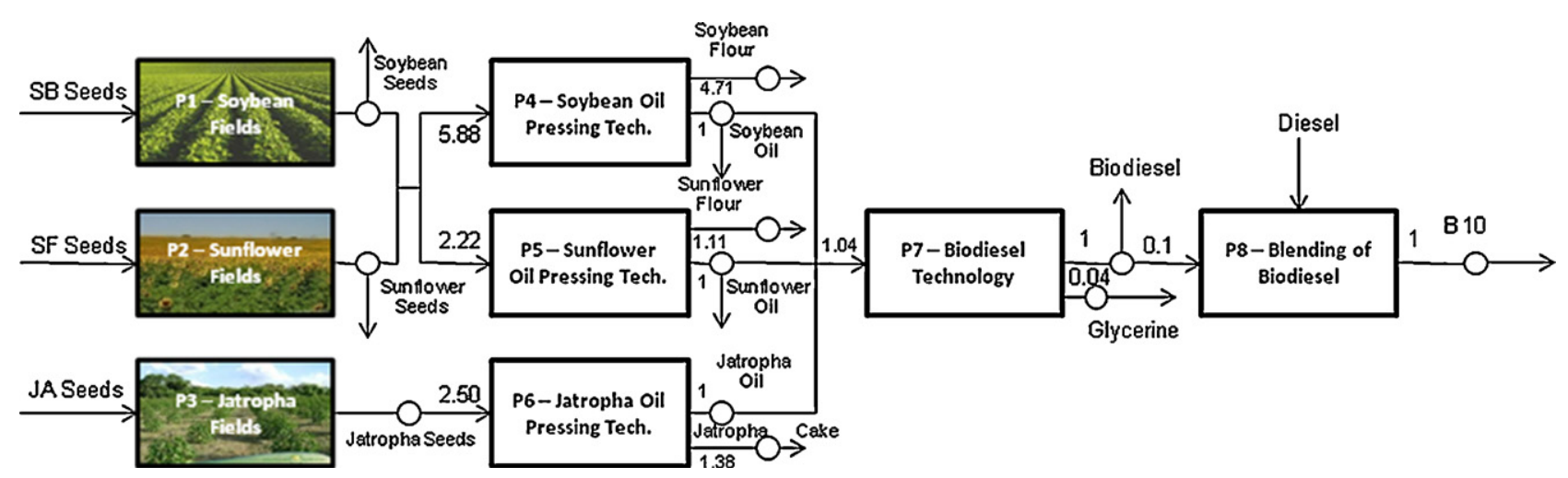

Fig. 1. Superstructure of technologies in each region.

\section{Mathematical model}

In this work, we propose a model for the design and optimization of the biodiesel supply chain in Argentina as a multiechelon problem. Alternative locations and capacities for farms, biomass storage sites, crushing plants, oil and byproducts storage, biodiesel production plan ts and storage facilities are included, as well as distribution centers to internal and external markets. The country is divided into twenty three regions (provinces) with different oil-toseed yields, production and transportation costs. Fig. 1 shows the superstructure of technologies within each region. Soybean (SB), sunflower (SF) and Jatropha (JA) are considered as raw materials, having into account land competition of soybean and sunflower crops. Sunflower crops have been considered in this work to evaluate land competition with soybean crops. Even though sunflower oil is too expensive to be dedicated to biodiesel production, it is the preferred oil for domestic consumption and currently sown areas must be distributed between these two traditional crops. The main feature of Jatropha crops is their capability to grow in marginal areas with extreme climatic conditions. As it is shown in Fig. 1, seeds are sent to storage facilities and can be either sold or processed in mills for oil and flour production and transported to different regions or to ports. Jatropha seeds cannot be processed in the same plants as soybean and sunflower due to Jatropha oil toxicity. Flour and oil are stored in each region and can be distributed as final products to other regions within the country or to ports for export. Oil can also be used as raw material in biodiesel plants. In these plants, vegetable oil is transesterified with methanol to methyl esters (biodiesel) and glycerol. Both products are stored and distributed. Biodiesel can be sold as pure biodiesel (B100) or transported to blending plants to obtain a $10 \%$ blend (B10), followed by storage and distribution.

In summary, the multiechelon model for the biodiesel supply chain includes twelve products (seed, oil and flour from soybean, sunflower and Jatropha, pure and blending biodiesel and glycerol), eight production technologies (fields, crushing plants, biodiesel plants and blending plants), three product transportation ways (trucks, railway, and ship) and a time horizon of 7 years.

Eq. (1) represents mass balances for product $i$ in region $g$ and time period $t$. The equation states that the inventory level $S W_{i g t-1}$ at time period $(t-1)$ plus production $P R_{i p g t}$, of product $i$ through all production technologies $p$ from $P P(i, p)$ set, purchases $I P_{\text {igt }}$ (imports) and quantity transported $Q_{i l g^{\prime} g t}$ in transport $l$, from region $g^{\prime}$ to region $g$ must be equal to current inventory $S W_{i g t}$ plus product sales $D P_{\text {igt }}$, mass consumed as raw material $P R_{\text {ipgt }}$, of product $i$ through all production technologies $p$ from $P R M(i, m)$ set and mass transported $Q_{i l g g^{\prime} t}$ from region $g$ to regions $g^{\prime} . P P(i, p)$ is the set of products $i$ produced by production technology $p$ and $P R M(i, p)$ is the set of products $i$ used as raw materials in production technology $p$. Index $l$ is introduced to take into account different ways of product transportation (truck, railway, train). Mass balances are formulated at each node in the superstructure of technologies, for each region (Guillen-Gosálbez \& Grossmann, 2010; Guillén-Gosálbez et al., 2010; Mele, Kostin, Guillén-Gosálbez, \& Jiménez, 2010).

$$
\begin{aligned}
S W_{i g t-1} & +\sum_{p \in P P(i, p)} P R_{i p g t}+I P_{i g t}+\sum_{l} \sum_{g^{\prime}} Q_{i l g^{\prime} g t}=S W_{i g t}+D P_{i g t} \\
& +\sum_{p \in P R M(i, p)} P R_{i p g t}+\sum_{l} \sum_{g^{\prime}} Q_{i l g g^{\prime} t} \forall i, g, t
\end{aligned}
$$

We have considered two types of raw material regarding seeding aspects; those requiring re-seeding yearly $(i \in S E E D(i))$ and those which remain cultivated up to the end of their life cycle $(i \in \operatorname{TREE}(i))$. Eq. (2) shows mass balances for the first group, which includes soybean (SB) and sunflower (SF) crops. In this equation, $A_{\text {igt }}$ is the sown surface area (ha) and $\eta$ the corresponding yield ( $\mathrm{t} / \mathrm{ha}$ ) for each region and time period, which is shown in Table 1. Fig. 2 shows

Table 1

Yield per region for soybean (SB) and sunflower (SF) crops.

\begin{tabular}{lrr}
\hline Region & Soybean (t/ha) & Sunflower $(\mathrm{t} / \mathrm{ha})$ \\
\hline BUE & 2676 & 1702 \\
CBA & 2601 & 1881 \\
CAT & 2532 & 1150 \\
COR & 1507 & 1200 \\
CHA & 1917 & 1155 \\
CHU & 0 & 0 \\
ENR & 2232 & 1564 \\
FOR & 1973 & 1185 \\
JUJ & 2793 & 1150 \\
LPA & 2039 & 1224 \\
LRJ & 0 & 0 \\
MEN & 0 & 0 \\
MIS & 1533 & 1100 \\
NEU & 0 & 0 \\
RNG & 0 & 0 \\
SAL & 2753 & 1150 \\
SJN & 0 & 0 \\
SLS & 2153 & 1701 \\
SCR & 0 & 0 \\
SFE & 3252 & 1214 \\
SET & 23,548 & 0996 \\
TDF & 0 & 0 \\
TUC & 2918 & 1100 \\
\hline Argentiean & & \\
\hline
\end{tabular}

Argentinean regions (Provinces): Buenos Aires (BUE), Córdoba (CBA), Catamarca (CAT), Corrientes (COR), Chaco (CHA), Chubut (CHU), Entre Ríos (ENR), Formosa (FOR), Jujuy (JUJ), La Pampa (LPA), La Rioja (LRJ), Mendoza (MEN), Misiones (MIS), Neuquen (NEU), Rio Negro (RNG), Salta (SAL), San Juan (SJN), San Luis (SLS), Santa Cruz (SCR), Santa Fe (SFE), Santiago del Estero (SET), Tierra del Fuego (TFG) and Tucuman (TUC). 


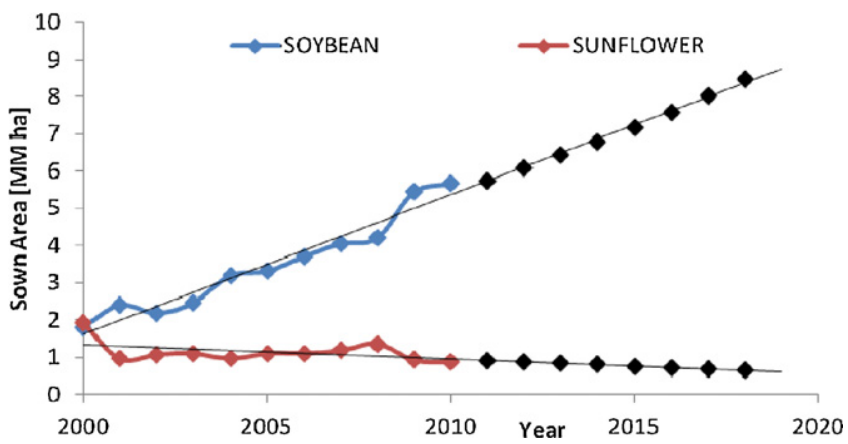

Fig. 2. Soybean and sunflower seed production: historical data (2000-2010) and estimations (2011-2018).

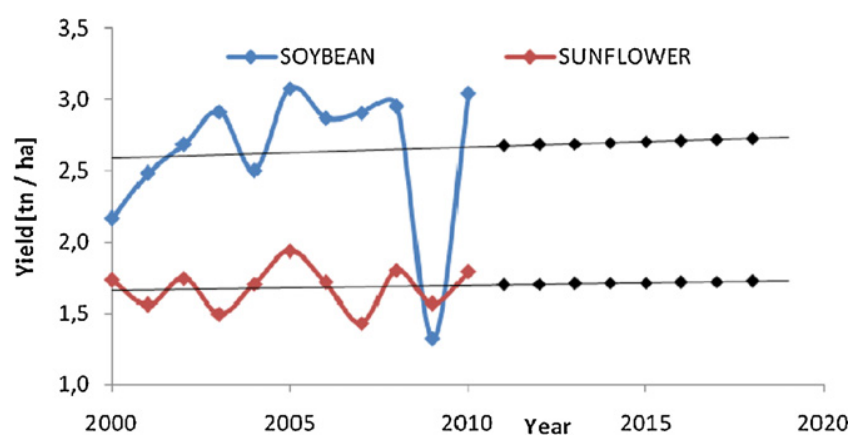

Fig. 3. Soybean and sunflower seed production: historical data (2000-2010) and estimations (2011-2018). Note: In 2009 there was an important period of drought that caused serious damage to crops.

historical and estimated data for sown area with soybean and sunflower (SAGPyA, 2010) and estimations up to 2018, which are used as upper bounds for the corresponding variables. Fig. 3 shows historical and estimated yields for soybean and sunflower production, which have been used as input data in Eq. (2).

$P R_{\text {ipgt }}=\eta_{\text {ipgt }} A_{\text {igt }} \quad i \in \operatorname{SEED}(i) ; p=P 1, P 2 ; \forall g, t$

The second group of raw materials includes Jatropha (JA), which is a perennial non-edible crop with increasing yield during the first five years and almost constant during the rest of its life cycle (40-50 years). This issue is modeled with Eq. (3), where total seed production for a given time period $t$ is calculated as the summation over the new available cultivation area in different time periods $t^{\prime} \leq t$ $\left(A_{\text {igt' }}\right)$ multiplied by the corresponding yield. Table 2 shows estimated yield $\left(\eta_{\text {ipgt }}\right)$ for Jatropha (JA) in each suitable region, in terms of agroecollogical aspects according to weather and soil conditions (Carballo et al., 2009).

$$
\begin{aligned}
P R_{\text {ipgt }}= & \sum_{t^{\prime}} \eta_{i p g\left(t-t^{\prime}+1\right)} A_{\text {igt }} \quad i \in \operatorname{TREE}(i), p=P 3, \forall g, t \\
& t^{\prime} \leq t
\end{aligned}
$$

Product conversion in crushing and biodiesel plants is represented by mass balance coefficients for each product associated

Table 2

Estimated yield for Jatropha curcas (JA) per region and plant age.

\begin{tabular}{llllll}
\hline Region & \multicolumn{7}{l}{ Plant age $(\mathrm{y})$} \\
& 1 & 2 & 3 & 4 & +5 \\
CAT-LRJ & 0.1 & 0.25 & 0.5 & 0.7 & 0.75 \\
JUJ - SAL & 0.2 & 0.5 & 1 & 1.4 & 1.5 \\
FOR & 0.5 & 1 & 2 & 2.7 & 3 \\
CBA - COR - CHA - ENR - MIS & 1 & 2.5 & 4.5 & 6.3 & 7 \\
$\quad$ - SFE - SET - TUC & & & & &
\end{tabular}

with a production technology and considering unitary coefficients for main products (Guillen-Gosálbez \& Grossmann, 2010), as it is shown in Fig. 1. Eq. (4) represents mass balances for each technology $p$, where $i^{\prime}$ is the main product and $\mu$ is the corresponding mass balance coefficient ( $t$ product $i / t$ main product).

$$
\begin{aligned}
P R_{\text {ipgt }}= & \mu_{i p} \sum_{i^{\prime} \in M P\left(i^{\prime}, p\right)} P R_{i^{\prime} p g t} \quad i=\text { SBoil, SFoil, Jaoil, SBflour, SFflour }, \\
& \times J \text { Acake }, \text { BioD }, \text { Gli, B10, } p=P 4, \ldots, P 8, \forall g, t
\end{aligned}
$$

\subsection{Crop competition}

Limited available land extension and climatic and edafic aptitude for the different raw materials have been taken into account by considering land usage within supply chain analysis. Official data on sown area and crop yields have been included for each one of the twenty three regions (www.ciara.com.ar; www.bolcereales.com). Fig. 2 shows the summation of sown areas over all provinces, for soybean and sunflower, respectively (in 2000-2010, historical data; in 2011-2018, estimations). Eq. (5) states that the total surface area sown with product $i$ is limited by the available land area to be sown $\left(A A_{g t}\right)$ in each region $g$ and period $t$.

$$
\sum_{i \in \operatorname{SEED}(i)} A_{i g t}+\sum_{t^{\prime} \leq t} A_{J A, g t} \leq A A_{g t} \quad \forall g, t
$$

where $A A_{g t}$ is a parameter calculated (Eq. (6)) as the summation

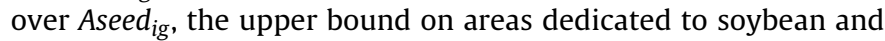
sunflower crops in region $g$ (see Fig. 2), plus the total unused suitable land (Aunusd $_{g}$ ) in region $g$ (INDEC, 2010) multiplied by the fraction corresponding to marginal zones $\left(F J A_{g}\right)$ and $G s$ is a coefficient that imposes a gradual increase in available area for crops (equal to 0.03 ), as follows:

$A A_{g t}=\left(\sum_{i \in S E E D(i)}\right.$ Aseed $_{\text {ig }}+$ Aunusd $\left._{g} F J A_{g}\right)(1+G s)^{t-1} \forall g, t$

The suitable area to sow J. curcas was estimated based on historical data of land statistics. The suitable regions for Jatropha crops (Carballo et al., 2009) were overlapped with free suitable area (area that could be cultivated but is not currently used, INDEC 2010). The upper bound on Jatropha sown area in region $g$ and time period $t$ is calculated with Eq. (7) as:

$$
\begin{gathered}
A_{J A, g t} \leq \lambda_{g t}\left(A A_{g t}-A_{S B, g t}-A_{S F, g t}\right)-\sum_{t^{\prime}} A_{J A, g t^{\prime}} \forall g, t \\
t^{\prime}<t
\end{gathered}
$$

As Jatropha is a new product, with an emerging market, the factor $\lambda_{g t}$ has been introduced to represent actual crop evolution, taking into account increasing investment on this product as it is being introduced in new markets. Values for these coefficients are shown in Table 3 and are the same for all regions, as they do not depend on agroecological aptitude, but on the confidence on this new product.

We have implicitly considered rotation in soybean and sunflower crops by imposing lower and upper bounds to available area $\left(A_{\text {igt }}\right)$ for seed $i$ in region $g$ and period $t$, as indicated by Eqs. (8) and (9):

$$
\begin{array}{ll}
A_{\text {igt }} \leq\left(1+{\text { MinR }) \text { Aseed }_{i g}(1+G s)^{t-1}}\right. & \forall i \in \operatorname{SEED}(i), g, t \\
A_{\text {igt }} \geq\left(1-{\text { MinR }) \text { Aseed }_{i g}(1+G s)^{t-1}}^{t-}\right. & \forall i \in \operatorname{SEED}(i), g, t
\end{array}
$$


Table 3

Coefficients $(\lambda)$ for increasing Jatropha sown areas.

\begin{tabular}{ll}
\hline Time $(\mathrm{y})$ & $\lambda$ \\
\hline 1 & 0.15 \\
2 & 0.25 \\
3 & 0.50 \\
4 & 0.90 \\
5 & 0.99 \\
6 & 1.00 \\
7 & 1.00 \\
\hline
\end{tabular}

where MinR is a parameter that takes into account crop rotation and has been fixed in 0.75 .

\subsection{Capacity equations}

Plant capacity for each production technology $p$ and region $g$ in time period $t, C P_{p g t}$ is limited by upper and lower bounds as indicated by Eqs. (10) and (11), where the minimal production level in each region is obtained affecting the installed capacity with a factor $\alpha(p) \leq 1$. As it can be noted, the summation is over $i$ products belonging to set $M P$, as plant capacity is calculated in terms of the main product in each production technology. The capacity of the production technology $p$ at region $g$ in any time $t$ is calculated from Eq. (12) by addition of existing capacity at the end of the previous period and the expansion in capacity carried out in $t\left(C E P_{p g t}\right)$. Upper and lower bounds of these expansions are given by Eqs. (13) and (14) where an integer variable $N P_{p g t}$ is included, providing information on the number of plants of technology $p$ to be installed in region $g$ and period $t$.

$\sum_{i \in M P(i, p)} P R_{\text {ipgt }} \leq C P_{p g t} \quad \forall p, g, t$

$\sum_{i \in M P(i, p)} P R_{\text {ipgt }} \geq \alpha_{p} C P_{p g t} \quad \forall p, g, t$

$C P_{p g t}=C P_{p g(t-1)}+C E P_{p g t} \quad \forall p, g, t$

$C E P_{p g t} \leq U B Q P_{p} N P_{p g t} \quad \forall p, g, t$

$C E P_{p g t} \geq L B Q P_{p} N P_{p g t} \quad \forall p, g, t$

The stored quantity of product $i$ in each warehouse is limited by the storage capacity $\left(C S_{\text {igt }}\right)$ in region $g$ and period $t$ for this product (Eq. (15)). We have included the possibility of building new warehouses $\left(N S_{i g t}\right)$ for each product, in each region and time period. Eqs. (16)-(18) are the corresponding storage capacity equations, where $C E S_{\text {igt }}$ corresponds to expansions in storage capacities for product $i$ in region $g$ and time period $t$.

$S W_{\text {igt }} \leq C S_{\text {igt }} \quad \forall i, g, t$

$C S_{i g t}=C S_{i g(t-1)}+C E S_{i g t} \quad \forall i, g, t$

$C E S_{\text {igt }} \leq U B Q S_{i} N S_{\text {igt }} \quad \forall i, g, t$

$C E S_{\text {igt }} \geq L B Q S_{i} N S_{\text {igt }} \quad \forall i, g, t$

Eq. (19) considers warehouses storage capacity in region $g$ in time period $t$ as twice the average storage level $\left(A S L_{i g t}\right)$, which is in turn calculated by dividing the total sales $\left(D P_{\text {igt }}\right.$, warehouse output flow) over the turnover ratio $\left(T O R_{i}\right)$ of product $i$, for the same region and period (Eq. (20)) (Guillen-Gosálbez \& Grossmann, 2010; Shapiro, 2001).

$2 A S L_{\text {igt }} \leq C S_{\text {igt }} \quad \forall i, g, t$
$A S L_{\text {igt }}=\frac{D P_{\text {igt }}}{T O R_{i}} \quad \forall i, g, t$
Storage capacity in ports has an important role due to the large amounts of product exports and it is modeled through Eqs. (21) and (22). The output flow is calculated as exports $\left(D E_{i g t}\right)$ plus domestic transportation to the remaining internal regions by ships and barges $\left(Q_{i S H I P g g^{\prime}}\right)$. In this model, we have not considered the possibility to expand storage capacity in ports $\left(C S P_{\text {igt }}\right)$.

$$
\begin{aligned}
& 2 A S L P_{\text {igt }} \leq \mathrm{CSP}_{\text {igt }} \quad \forall i, g \in \operatorname{PORTS}(\mathrm{g}), t \\
& D E_{i g t}+\sum \quad Q_{i^{\prime} S H I P^{\prime} g g^{\prime} t}=A S L P_{i g t} T_{O R P} \quad \forall i, g \in \operatorname{PORTS}(g), t \\
& g^{\prime} \in \text { PORTS } \\
& g^{\prime} \neq g
\end{aligned}
$$

Total sales $\left(D P_{\text {igt }}\right)$ are composed of domestic sales $\left(D D_{\text {igt }},\right)$ and exports $\left(D E_{\text {igt }}\right)$, as it is shown in Eq. (23). Lower and upper bounds have been imposed in Eqs. (24)-(27), considering the local demand $\left(D D M_{i g t}\right)$ affected by the factor $D$ sat that stands for the minimum desired satisfaction level and taking into account a time projection for product requirement in international markets $(\mathrm{GE}=3 \%)$.

$$
\begin{aligned}
& D P_{i g t}=D D_{i g t}+D E_{i g t} \quad \forall i, g, t \\
& D D_{i g t} \leq D D M_{i g t} \quad \forall i, g, t \\
& D D_{\text {igt }} \geq \text { Dsat }_{\text {igt }} D D M_{\text {igt }} \quad \forall i, g, t \\
& D E_{\text {igt }} \leq \operatorname{EMAX}_{i}(1+G E)^{t-1} \quad \forall i, g, t \\
& D E_{i g t} \geq \operatorname{EMIN}_{i}(1+G E)^{t-1} \quad \forall i, g, t
\end{aligned}
$$

The quantity transported between different regions is limited by upper and lower bounds, as indicated by Eqs. (28) and (29). In these equations, binary variables $\left(Y_{\text {ilgg't }}\right)$ have been associated to each transportation technology $l$ (TRUCK, RAILWAY, SHIP) between different regions $g$ and $g^{\prime}$ in time period $t$ for each product $i$ that is transported. To reduce the number of binary variables, we have modeled shipping between nodes of the supply chain as annual contracts; i.e., if the contract is signed $\left(X_{i g g^{\prime} t}=1\right)$, transportation of product $i$ between regions $g$ and $g^{\prime}$ can take place in all periods of the corresponding year, with lower and upper bounds. If the contract does not exist $\left(X_{i g g^{\prime} t}=0\right)$, transportation of product $i$ between regions $g$ and $g^{\prime}$ cannot occur.

$Q_{i l g g^{\prime} t} \leq \operatorname{Qup}_{\text {lg }} Y_{\text {ilgg't }} \quad \forall i, l, g, g^{\prime} \neq g, t$
$Q_{i l g g^{\prime} t} \geq \operatorname{Qlo}_{\text {lg }} Y_{\text {ilgg't }} \quad \forall i, l, g, g^{\prime} \neq g, t$

Eq. (30) imposes that transportation of product $i$ in period $t$ from region $g$ to $g^{\prime}$ cannot occur simultaneously with transportation of the same product from region $g^{\prime}$ to $g$ in the same time period.

$X_{i g g^{\prime} t}+X_{i g^{\prime} g t} \leq 1 \quad \forall i, g, g^{\prime} \neq g, t$

$Y$ and $X$ are related through the following logic constraint:

$\left(\underset{l \in L}{\vee} Y_{i l g g^{\prime} t}\right) \Rightarrow X_{i g g^{\prime} t} \quad \forall i, g, g^{\prime} \neq g, t$

which has been re-written in Eqs. (32) and (33) as:

$X_{\text {igg't }} \geq Y_{\text {ilgg't }} \quad \forall i, l, g, g^{\prime} \neq g, t$

$X_{i g g^{\prime} t} \leq \sum_{l} Y_{\text {ilgg't }} \quad \forall i, g, g^{\prime} \neq g, t$

It is necessary to point out that if no constraints are imposed on the means of transportation, the natural selection is railway, as it is associated to lower costs. However, during the last twenty years transportation by truck has been favored both by political reasons and by the lack of maintenance to railways. Consequently, even though railway transportation is less expensive, it is also less efficient and reliable. This fact has been included by limiting railway 
transportation only to ten of the twenty three regions (BUE, CBA, ENR, LPA, MEN, NEU, RNG, SJN, SLS, SFE), which have better railway infrastructure and by imposing a lower bound to truck transportation, which indirectly limits railway transportation. Thus, Eq. (34) imposes a minimum percentage of total transportation $(\varepsilon)$ by truck:

$\sum_{i} \sum_{g} \sum_{g^{\prime} \neq g} \sum_{t} Q_{i \text { iRUCK } g g^{\prime} t} \geq \varepsilon \sum_{i} \sum_{l \neq \text { TRUCK }} \sum_{g} \sum_{g^{\prime} \neq g} \sum_{t} Q_{i l g g^{\prime} t}$

The objective function for the MILP problem is Net Present Value $(N P V)$ for the biodiesel supply chain, as stated in Eq. (35), where all cash flows $C F_{t}$ are discounted up to present with a discount rate $I R$, while $M V$ is the market value of investments at the end of the time horizon. Economic variables have been calculated with the convention of End of Year with the exception of Fixed Capital Investment. The amount of money invested in the supply chain at the beginning of year $t$, will begin to produce benefits from year $t+1$ onwards. That is why $\left(F I_{t+1}\right)$ have been included in the calculation of $C F_{t}$ in Eq. (36), with profit before taxes $\left(P R B T_{t}\right)$ and the corresponding depreciation $\left(D E P_{t}\right)$ evaluated for year $t$. TR denotes the fix tax rate. The market value is calculated by Eq. (38) where WCF is the working capital factor introduced as a parameter in the model.

$N P V=\left(\sum_{t} \frac{C F_{t}}{(1+I R)^{t}}\right)+\frac{M V}{(1+I R)^{t}}$

$C F_{t}=(1-T R) P R B T_{t}+T R D E P_{t}-F C I_{t+1} \quad \forall t<t_{E N D}$

$C F_{t}=(1-T R) P R B T_{t}+T R D E P_{t} \quad t=t_{E N D}$

$M V=\sum_{t}(1-W C F) F C I_{t}-D E P_{t}$

The depreciation of investment, as given in Eq. (39), has been taken into account considering the straight line method that includes working capital factor WCF and salvage value factor SVF (Douglas, 1988).

$D E P_{t}=\left(\sum_{t^{\prime}} F C I_{t^{\prime}}\right) \frac{(1-W C F)(1-S V F)}{N T} \forall t$

Facilities capital investments $\left(F C I_{t}\right)$ have been calculated by Eq. (40) considering capital investments on new plants $\left(P C I_{p g t}\right)$ and warehouses $\left(S C I_{i g t}\right)$. Both variables are estimated as the summation of fix and variable costs, as it shown in Eqs. (41) and (42), where $F C I P_{p}$ and $F C I S_{i}$ are individual fix plant and storage costs and $V C I P_{p}$ and $V C I S_{i}$ are the related individual variable costs, respectively.

$F C I_{t}=\sum_{g}\left(\sum_{p} P C I_{p g t}+\sum_{i} S C I_{i g t}\right) \quad \forall t$

$P C I_{p g t}=F C I P_{p} N P_{p g t}+V C I P_{p} C E P_{p g t} \quad \forall p, g, t$

$S C I_{i g t}=F C I S_{i} N S_{i g t}+V C I S_{i} C E S_{i g t} \quad \forall i, g, t$

Eq. (43) gives the profit before tax $\left(P R B T_{t}\right)$ as a function of incomes $\left(R E V_{t}\right)$, facility operating costs $\left(F O C_{t}\right)$ and transportation costs $\left(T O C_{t}\right)$. Revenues are defined by Eq. (44) as the difference between income from sales and imports costs, where $E P R_{i}$ and $D P R_{i}$ denote individual product price in external and domestic markets, respectively, and $I P P R_{i}$ represents the individual importation cost for product $i$. Facility operating costs $\left(F O C_{t}\right)$ of supply chain (Eq. (45)) include production and storage costs calculated from individual production costs for each technology $\left(U P C_{p g t}\right)$ and individual storage costs for each product $\left(U S C_{i g t}\right)$. Finally, Eq. (46) gives transportation operating costs $\left(T O C_{t}\right)$ considering different transportation technologies. The scalar $F_{i l}$ denotes the unitary cost of each transportation type for the different products and $Q_{i l g g^{\prime} t}$ the quantities transported along the distance $D T_{g g^{\prime}}$.

$$
\begin{aligned}
& P R B T_{t}=R E V_{t}-F O C_{t}-T O C_{t} \quad \forall t \\
& R E V_{t}=\sum_{i} \sum_{g}\left(E P R_{i} D E_{\text {igt }}+D P R_{i} D D_{\text {igt }}-I P P R_{i} I P_{\text {igt }}\right) \quad \forall t \\
& F O C_{t}=\sum_{g}\left(\sum_{p} U P C_{p g t} \sum_{i} P R_{\text {ipgt }}+\sum_{i} U S C_{i g t} A S L_{i g t}\right) \quad \forall t \\
& T_{O C C_{t}}=\sum_{i} \sum_{l} \sum_{g} \sum_{g^{\prime}} Q_{i l g g^{\prime} t} D T_{g g^{\prime}} F_{i l} \quad \forall t
\end{aligned}
$$

\section{Results and discussion}

The MILP model for the design and optimization of the biodiesel supply chain in Argentina has been implemented in GAMS (Brooke, Kendrick, Meeraus, \& Raman, 2011). We consider three types of raw materials for seed and oil production (soybean, sunflower and Jatropha seeds) plus methanol for oil transesterification to biodiesel nine products (the corresponding oil and flour, pure and blending biodiesel and glycerol), eight production technologies (fields, crushing plants, biodiesel plants and blending facilities) and three product transportation technologies (truck, railway and ship) in each region. The time horizon is seven years (2012-2018), divided into 84 time periods. We have solved three MILP problems (M1, M2, M3) for different values of $\varepsilon$ in Eq. (34); i.e., imposing increasing percentages of transportation by truck. The problem has 259,749 constraints, 387,481 continuous variables and 53,004 discrete ones. The MILP problems have been solved with CPLEX 11.2. Table 4 shows computational details for the three cases. In problem M1, there is no constraint on the type of transportation means and the problem has been solved in $1265 \mathrm{~s}$ with an optimality gap of $0.01 \%$ in an Intel Core 2 Duo P8600 2.40 GHz, 3 GB RAM processor. Problems M2 and M3 represent the actual situation of the Argentinean means of transportation. We have imposed higher percentages of truck transportation, greater than 25 and 40\%, respectively. This situation occurs due to the fact that even though railway transportation is less expensive, it is less efficient and reliable, as a result of lack of maintenance for railways. Therefore, most of the products are currently transported by truck. Regarding numerical results, it can be pointed out that the higher the percentage of truck transportation, the more computationally expensive the problem becomes and the lower the net present value for the entire supply chain.

Optimal distribution of total land for crops is shown in Fig. 4 along the entire time horizon. An increment of $40 \%$ of sown land with soybean and $100 \%$ for sunflower is required to satisfy increasing internal and external demand of biodiesel and intermediate products (mainly sunflower oil) in the time horizon, while an important increase in Jatropha sown areas (on the order of 3.5 times in the fifth year, been kept constant through the seventh

Table 4

Computational details.

\begin{tabular}{llll}
\hline & $\begin{array}{l}\text { Problem } \\
\text { M1 }\end{array}$ & $\begin{array}{l}\text { Problem } \\
\text { M2 }\end{array}$ & $\begin{array}{l}\text { Problem } \\
\text { M3 }\end{array}$ \\
\hline Objective function (NPV) & 117,325 & 115,247 & 113,348 \\
Gap [\%] & $0.0101 \%$ & $0.0121 \%$ & $0.0192 \%$ \\
Resolution time [s] & 1356.09 & 1375.25 & 3143.52 \\
Truck & $3.1 \%$ & $25 \%$ & $40 \%$ \\
Railway & $92.4 \%$ & $65.4 \%$ & $53.8 \%$ \\
Ship & $4.5 \%$ & $9.6 \%$ & $6.2 \%$ \\
\hline
\end{tabular}




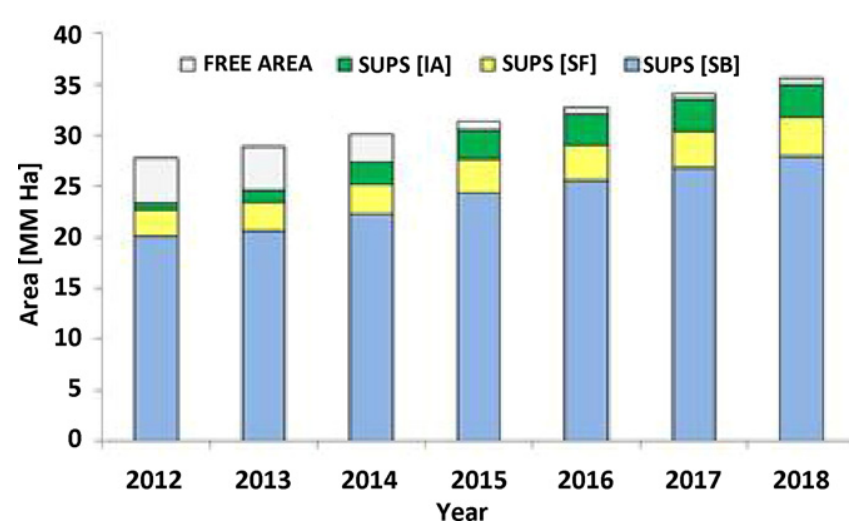

Fig. 4. Optimal surface area distribution for soybean (SB), sunflower (SF) and Jatropha (JA) crops 2012-2018.

year) indicates the trend to replace biodiesel production based on soybean and sunflower oil by alternative ones. This trend is remarkable in regions with larger marginal zones and extreme climatic conditions, as it is the case of Chaco ( $\mathrm{CHA})$, a northern region in Argentina (Fig. 5). In this case, there is an important increase of areas dedicated to Jatropha, while areas dedicated to soybean crops remain constant. Furthermore, additional sown areas are required for sunflower, mainly as a result of the increasing demand of sunflower oil as a final edible product. The increasing volume of the biodiesel supply chain is associated to a consequent growth in oil production (Fig. 6), that will be sold as food or as raw material for biodiesel plants. Fig. 7 shows that sunflower oil is not used as raw material for biodiesel blending and soybean oil is gradually been replaced by Jatropha oil, in a clear trend to keeping sunflower and soybean oil within food markets. Even when there are currently a few plants to process Jatropha seeds, Jatropha oil production of oil is not significant and we consider its initial value of zero in 2012 . During the following years, Jatropha oil obtained in new mills is processed as raw material for biodiesel production, as it can be seen when comparing Figs. 6 and 7. On the other hand, plant and storage capacities must be expanded to process the increasing flow of raw materials and products. Numerical results show that fifty four new production plants (oil plus biodiesel) must be incorporated to the Argentinean biodiesel supply chain throughout the seven-year time horizon, to increase biodiesel capacity in 1,800,000 t/y. Fig. 8 shows that there are forty two new oil plants and twelve biodiesel ones. It can also be seen that new biodiesel plants are mainly built in regions where there are currently no plants, within marginal

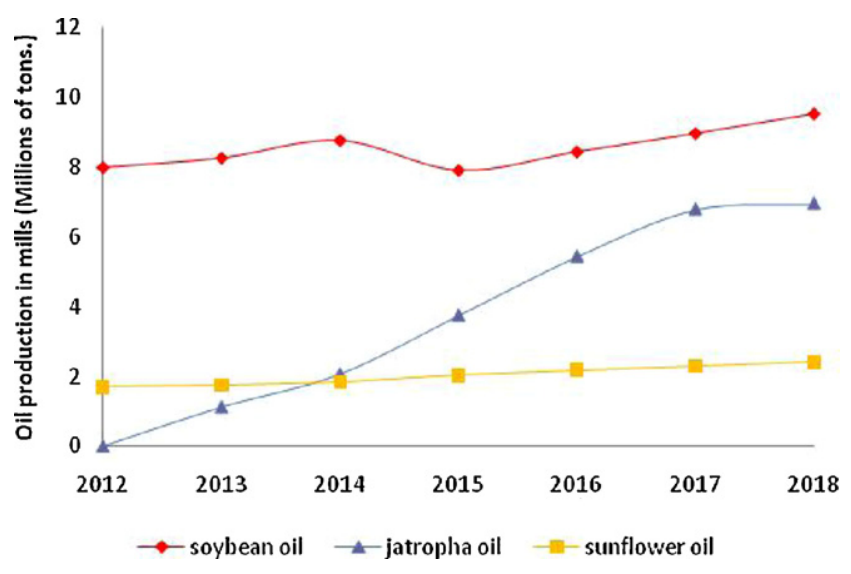

Fig. 6. Oil plant production throughout the entire time horizon.

areas where Jatropha is being sown. Oil and biodiesel production capacity in Argentina is shown in Fig. 9, where it can be seen the current production (2012 year) and the corresponding increment in the following years. Current capacity for biodiesel production per region is 700,$000 ; 400,000 ; 375,000 ; 60,000 ; 90,000 ; 3,100,000$ and 150,000 t/y for Buenos Aires (BUE), Córdoba (CBA), Entre Ríos (ENR), Neuquen (NEU), San Luis (SLS), Santa Fe (SFE) and Santiago del Estero (SET) regions, respectively.

Regarding warehouses, forty three new ones are Jatropha flour residual cake - warehouses (currently there are neither plants nor warehouses based on Jatropha raw material), one pure biodiesel warehouse and eighteen blend biodiesel warehouses. Fig. 10 shows current and future storage capacity for the different products of the supply chain.

Soybean and sunflower seeds can be sold in domestic or external markets or alternatively, consumed as raw material in mills to produce oil and flour as main products. In the same way, the produced soybean oil can be used as raw material in biodiesel plants and also it can be sold, mainly in external markets. The ratio between exports and domestic sales in the biodiesel supply chain is indicated by the areas in Fig. 11(a)-(d). Fig. 11(c) shows that soybean oil domestic sales can be reduced from 4 MM tons in current situation to zero in 2017. This result indicates that this edible oil could be gradually replaced by Jatropha oil for biodiesel production; it also shows the convenience of selling soybean oil in external food markets instead of using it as raw material for biodiesel production. $\square$ SUPS(SB) $\square$ SUPS(SF) $\square$ SUPS(JA) $\square$ SUPFREE

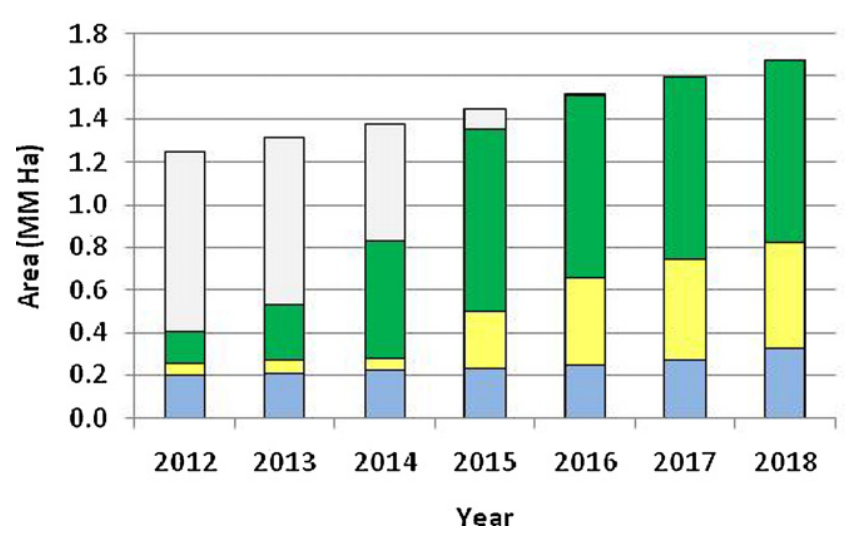

Fig. 5. Optimal surface area distribution for soybean (SB), sunflower (SF) and Jatropha (JA) crops in Chaco (CHA) region in Argentina.

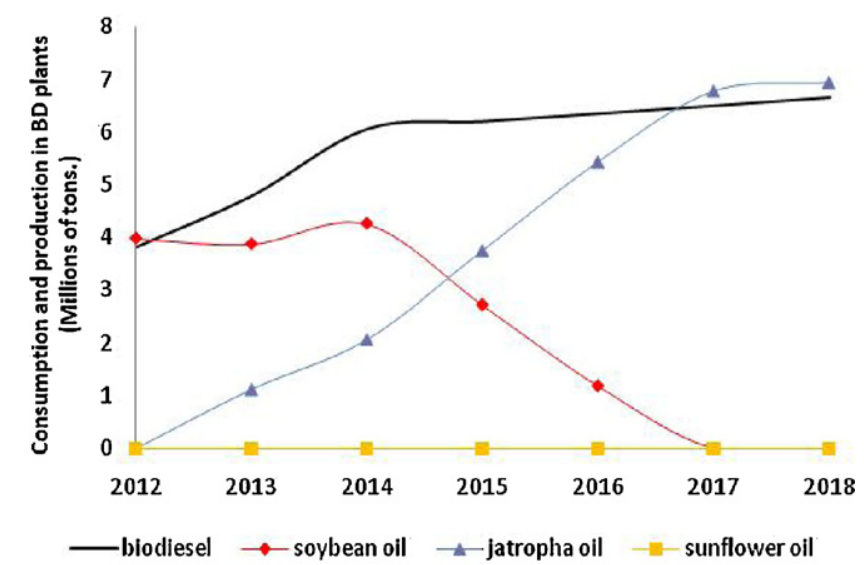

Fig. 7. Oil sold as raw material in biodiesel plants. 


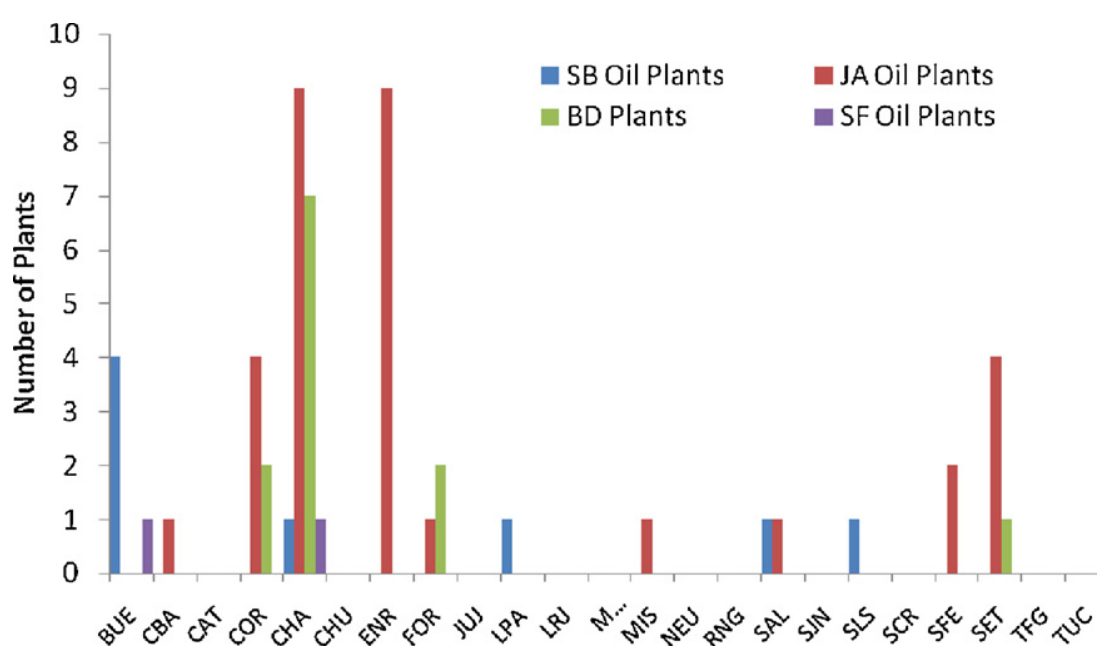

Fig. 8. New plants per region (23 regions) throughout the entire time horizon (2012-2018).

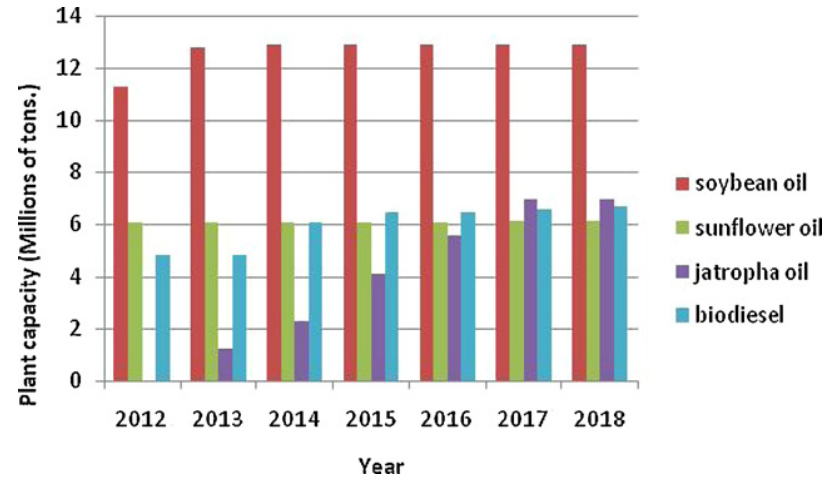

Fig. 9. Total plant capacity 2012-2018(2012 corresponds to current installed capacity).

Production and storage costs for the biodiesel supply chain throughout the time horizon are reported in Table 5. Results indicate that total storage cost is approximately $10 \%$ of the total production cost, which is of $80,086 \mathrm{MM}$ U\$D for the entire time horizon. Numerical results also determine directions and transportation ways of intermediate and final products among the twenty three geographical regions.

Finally, a sensitivity analysis has been carried out both on domestic and external demand. In the base case, demands for every product can vary between lower and upper bounds throughout the planning horizon. These bounds could be interpreted as minimal

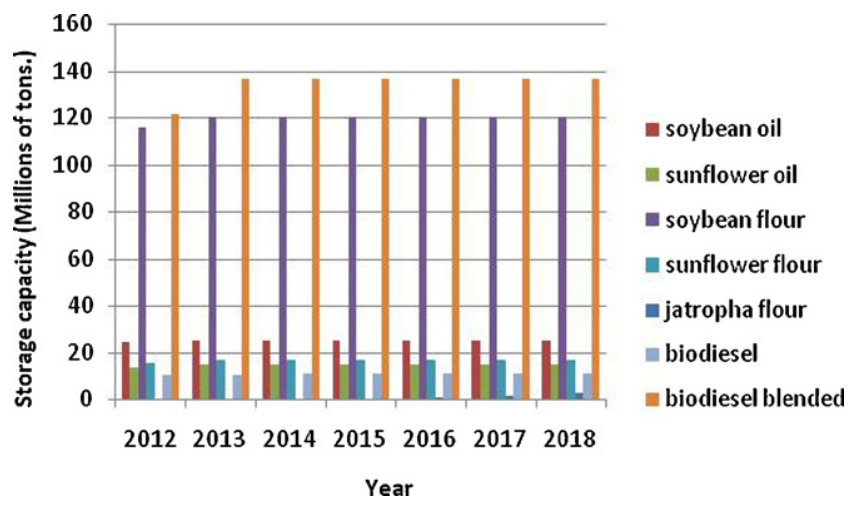

Fig. 10. Total storage capacity required from 2012 to 2018 year (2012 year indicates current installed capacity). percentage of satisfied demand and maximum demand and have been modified to analyze their influence on sales. We have solved four additional subproblems considering a $25 \%$ variation in external demand bounds (P1, P2) and a $20 \%$ variation in domestic demand bounds (P3, P4) throughout the time horizon, as it is shown in Tables 6 and 7, respectively.

In the base case, soybean seeds exports are at their upper bound, soybean oil exports are close to their lower bound and the biodiesel international sales goes from lower to upper bound throughout the time horizon. When the bounds on external demand decrease (P1), soybean seed exports decrease and so does biodiesel exports, while soybean oil exports increase. This behavior is mainly due to the fact that mills capacity does not vary significantly (Figs. 12-14). On the other hand, when the bounds on demand increase (P2), there is an increase in soybean seed and biodiesel exports, with a decrease in soybean oil sales (Figs. 12-14). It can be noted that it is more convenient to produce and sell biodiesel rather than

Table 5

Production and storage costs.

\begin{tabular}{lcl}
\hline Time horizon [y] & Production cost [MM U\$D] & Storage cost [MM U\$D] \\
\hline 1 & 9071 & 1057 \\
2 & 9602 & 1100 \\
3 & 10,470 & 1162 \\
4 & 11,510 & 1094 \\
5 & 12,392 & 1214 \\
6 & 13,203 & 1322 \\
7 & 13,837 & 1403 \\
\hline
\end{tabular}

Table 6

Numerical results for different scenarios on exports bounds.

\begin{tabular}{llll}
\hline & P1 & Base case & P2 \\
\hline Variation on demand bounds [\%] & -25 & 0 & +25 \\
NPV [MM USD] & 113,501 & 115,247 & 117,959 \\
Solution time [s] & 141.227 & 1375.25 & 233.284 \\
Gap [\%] & 0.0173 & 0.0121 & 0.0199 \\
\hline
\end{tabular}

Table 7

Numerical results for different scenarios on domestic sales bounds.

\begin{tabular}{llll}
\hline & P3 & Base case & P4 \\
\hline Variation on demand bounds [\%] & -20 & 0 & +20 \\
NPV [MM USD] & 109,093 & 115,247 & 120,893 \\
Solution time [s] & 1210.209 & 1375.25 & 2031.725 \\
Gap [\%] & 0.0146 & 0.0121 & 0.0200 \\
\hline
\end{tabular}




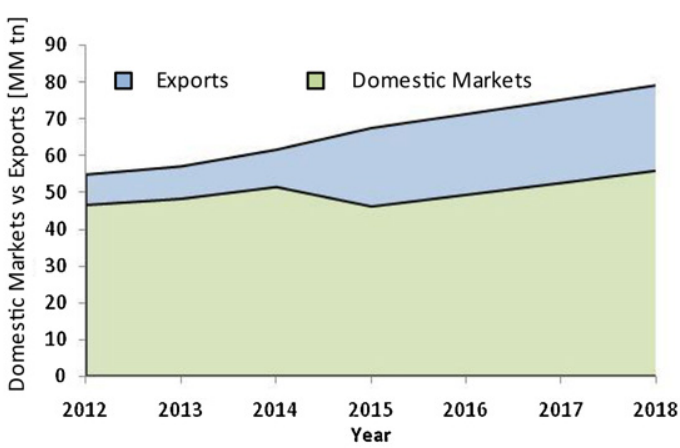

(a) soybean seeds

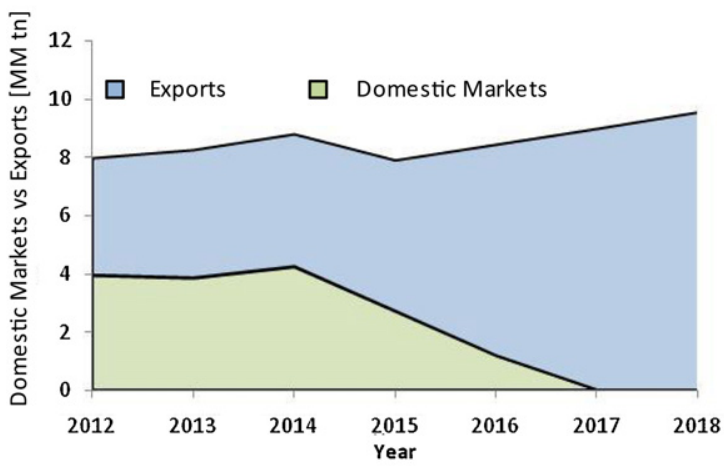

c) soybean oil

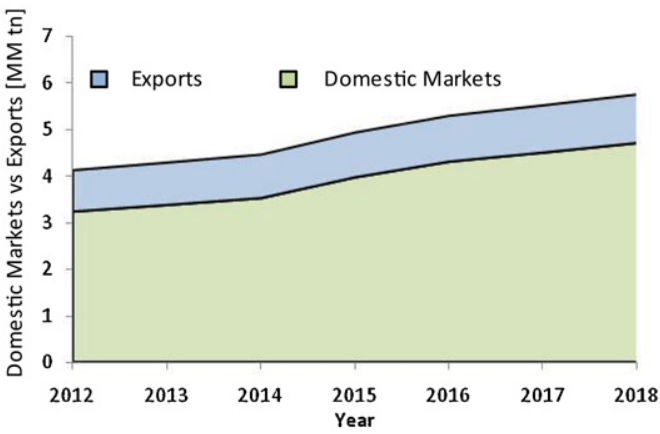

(b) sunflower seeds

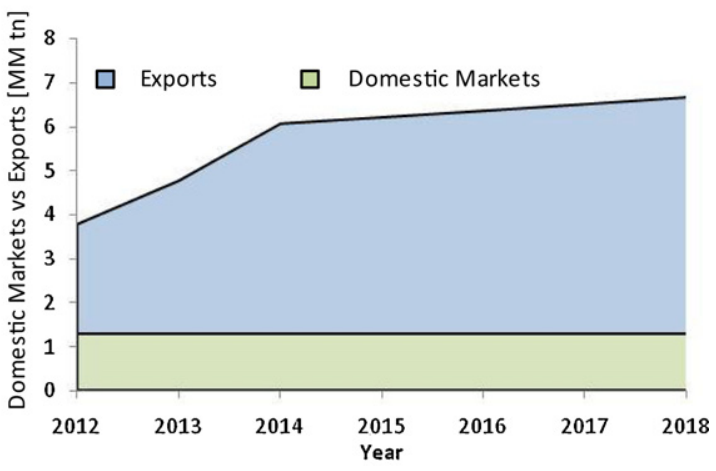

(d) biodiesel

Fig. 11. Exports and domestic sales of intermediate and final products in the biodiesel supply chain.

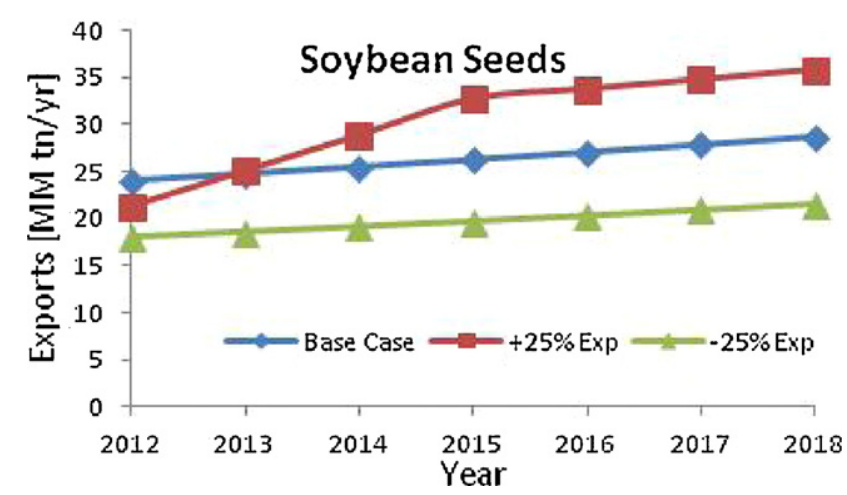

Fig. 12. Soybean seed exports profiles for $25 \%$ variation in external demand.

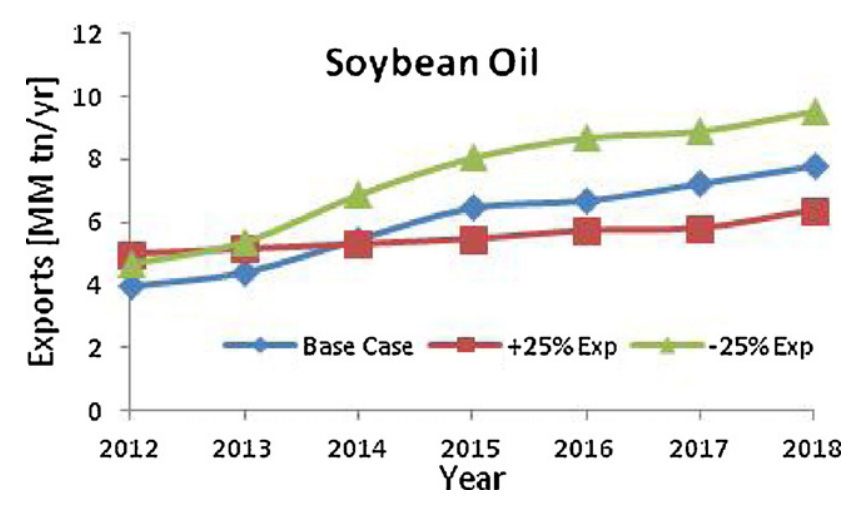

Fig. 13. Soybean oil exports profiles for $25 \%$ variation in external demand. oil due to the special export tax rates on biodiesel, which are lower than those related to soybean oil and have been included in the supply chain model. When bounds on domestic sales increase (P3), so do sales for all products and, consequently, the objective function. The opposite behavior occurs when domestic demand decreases (P5).

Figs. 15-18 show maps for the Argentinean biodiesel supply chain with the situation in the fourth year of the project. In these maps, the darker the color, the larger the area sown with soybean (regions in with no color do not have soybean crops). Circles represent existing capacity of production and stars represent investment made in the fourth year. The arrows represent material flows. Southern regions are referred to as CHU, STC and TDF

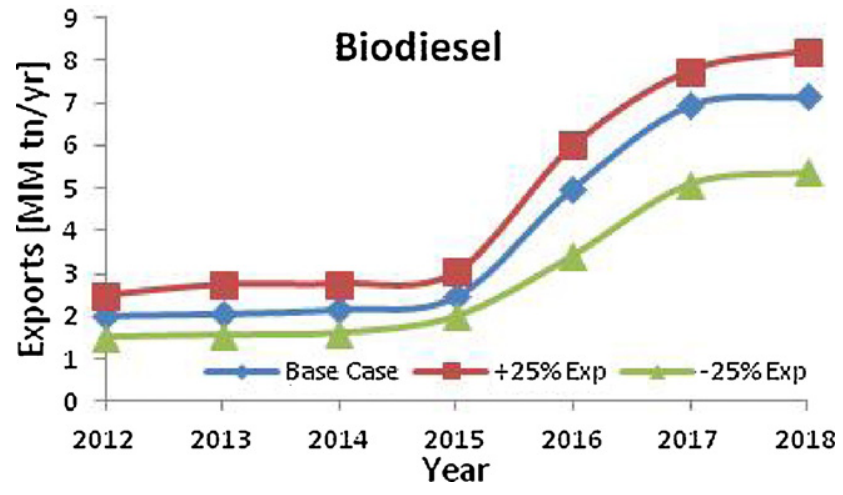

Fig. 14. Biodiesel exports profiles for $25 \%$ variation in external demand. 


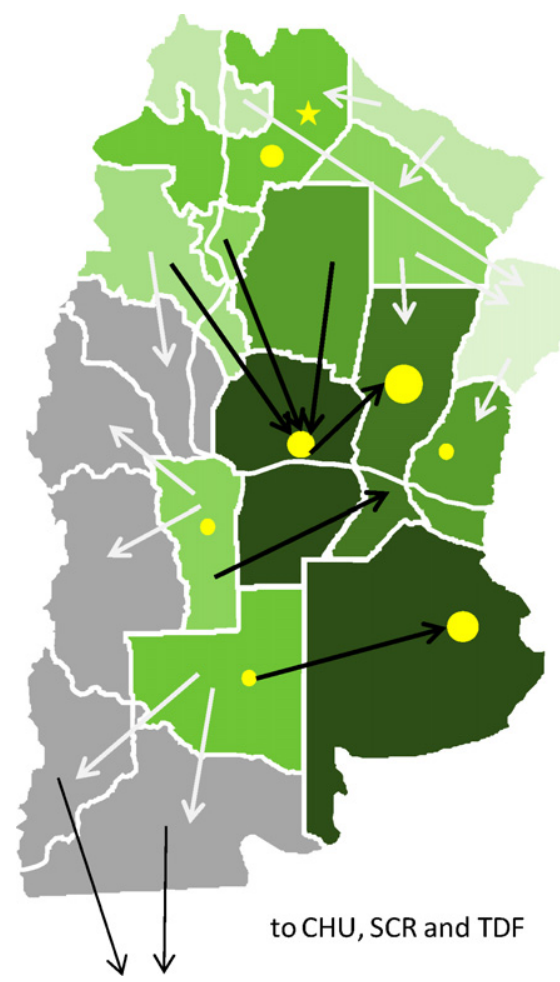

Fig. 15. Soybean seed production regions and transportation flows in the fourth year of planning horizon.

and not included in the map because they are only consumers (see arrows). Fig. 15 shows soybean production regions and soybean seed transportation flows among regions. Fig. 16 shows mills and oil and flour flows. While black arrows represent the main transport of oil and blue ones, the main transport of flour, gray arrows

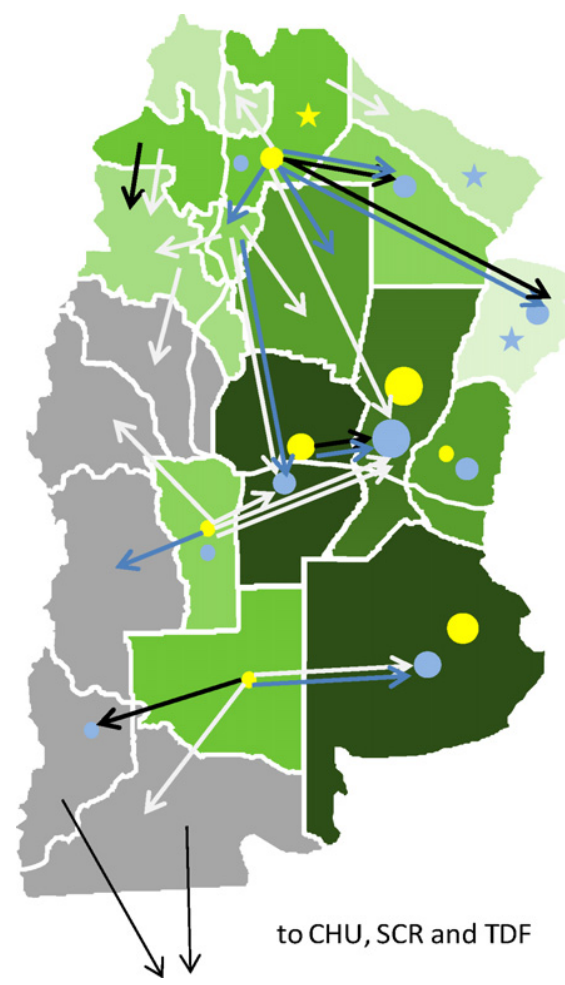

Fig. 16. Oil and flour and transportation flows, existing mills and new investments in the fourth year of planning horizon.

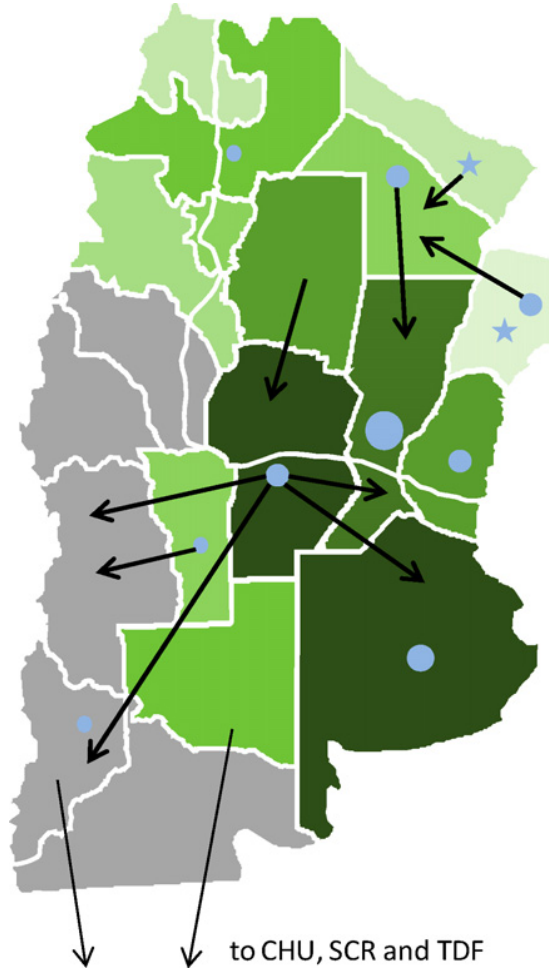

Fig. 17. Pure biodiesel transportation flows, existing biodiesel plants and new investments in the fourth year of planning horizon.

represent minor transport for both products (less than 50,000 t/y for seeds and flour and less than $5000 \mathrm{t} / \mathrm{y}$ for oil). It can be noted that new investments (blue stars) correspond to Jatropha oil plants in northwestern regions (FOR and COR). Figs. 17 and 18 show fuel grade biodiesel flows (used to produce the blends with diesel and

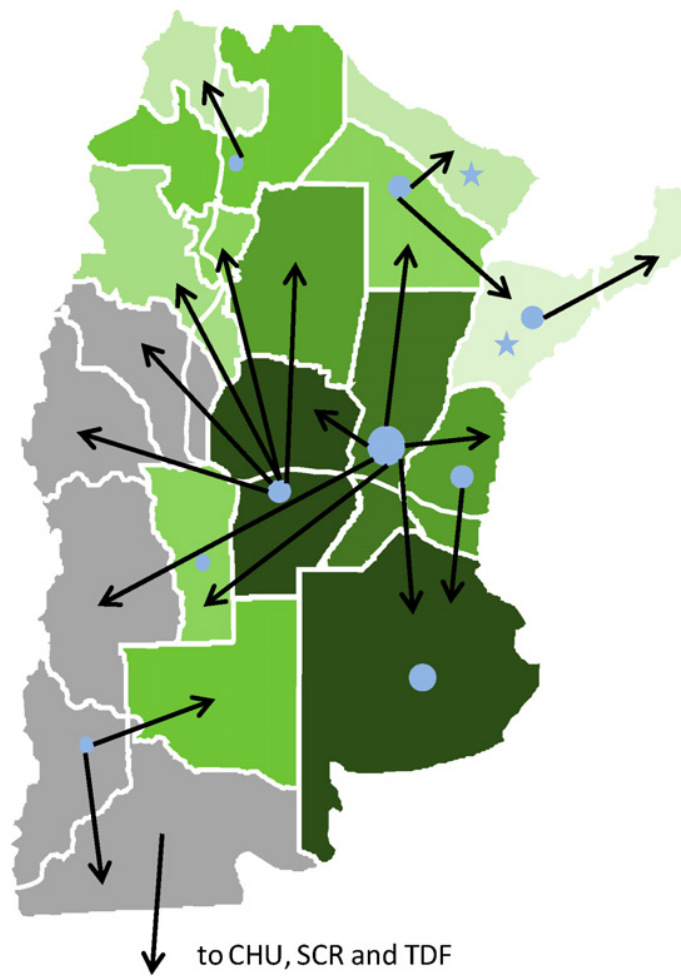

Fig. 18. B10 transportation flows, existing blending plants and new investments in the fourth year of planning horizon. 
to satisfy international demand). It can be noted that SFE, BUE and CBA regions produce most of the soybean seeds of the country (this feature becomes even more evident due to the partial replacement of soybean oil with J. curcas oil in biodiesel production in the northern regions). SFE region plays a very important role in the productive industry of biodiesel and soybean mills and big quantities of product are exported from this region. BUE is a productive and a net and very strong consuming region (not only due to the high local consumption but also because of the exports). CBA region plays an "intermediate" role, receiving products from different regions of the country and distributing them over many provinces.

\section{Conclusions}

In this work, we have performed the design and optimization of the Argentinean biodiesel supply chain, including land competition between crops, taking into account sowing areas for different raw materials up to intermediate and final product distribution in internal and external markets. Crop rotations have been implicitly taken into account by appropriate upper and lower bounds on sown areas. Numerical results show that the development of the biodiesel supply chain in Argentina requires an increasing use of land to produce oil and flour to satisfy future domestic and external demand. A gradual replacement of traditional crops by alternative ones (Jatropha) to produce biodiesel is determined. Jatropha can grow in marginal areas so current sown areas are extended to marginal ones, especially in regions which are not traditional oil producers, like Chaco, Santiago del Estero and Formosa. The MILP model has been implemented in GAMS providing a powerful decision-making tool that can be applied to other regions or countries by adjusting specific data.

\section{Acknowledgements}

The authors gratefully acknowledge financial support from the National Research Council (CONICET), Universidad Nacional del Sur and ANPCYT from Argentina and Universidad Técnica Federico Santa María, from Chile.

\section{References}

Achten, W. M. J., Verchot, L., Franken, Y. J., Mathijs, E., Singh, V. P., Aerts, R., et al. (2008). Jatropha bio-diesel production and use. Biomass and Bioenergy, 32(12), 1063-1084.

Akgul, O., Zamboni, A., Bezzo, F., Shah, N., \& Papageorgiou, L. G. (2011). Optimizationbased approaches for bioethanol supply chains. Industrial $\mathcal{E}$ 'Engineering Chemistry Research, 50, 4927-4938.

Andersen, F., Iturmendi, F., Espinosa, S. N., \& Diaz, M. S. (2010). Optimal planning of biodiesel supply chain in Argentina with alternative oil sources. In AIChE annual meeting 7-12 November 2010, Salt Lake City, USA

Andersen, F., Iturmendi, F., Espinosa, S., \& Díaz, M. S. (2012). Optimal design and planning of biodiesel supply chain with land competition. Savannah, GA, USA Foundations of Computer-Aided Process Operations FOCAPO, January.

Andreani, P. (2008). Biodiesel in Argentina. In National biodiesel board conference Orlando, USA.

Brooke, A., Kendrick, D., Meeraus, A., \& Raman, R. (2011). GAMS: A user guide.

CADER (2010). Cámara Argentina de Energías Renovables. Available from www.argentinarenovables.org.

CARBIO (2010). Cámara Argentina de Biocombustibles. Available from www.carbio.com.ar.

Carballo, S., Flores, N., \& Hilbert, J. (2009). Evaluación de las vulnerabilidades y potencial de expansión del cultivo de Piñón manso (Jatropha curcas L.) en Argentina. Instituto Nacional de Tecnología Agropecuaria (Vol.9, pp. 99-106). INTA, Buenos Aires, AR, Idia XXI 11.

Casotti, W. (2006a). Obtención de biodiesel (metil/etil esteres) por medio del uso de aceites de las Euforbiáceas Jatropha macrocarpa y Jatropha hieronymi. Jornadas sobre Biocombustibles, Cultivos no Tradicionales y su Impacto en las Economías Regionales, Mendoza, Argentina.

Casotti, W., \& Font, F. (2006b). Cultivos alternativos para zonas áridas. Especies, rendimientos, beneficios y dificultades. Jornadas de Biocombustibles. Jornadas sobre Biocombustibles, Cultivos no Tradicionales y su Impacto en las Economías Regionales. Mendoza, Argentina.

Dam, J., Faaij, A. P. C., Hilbert, J., Petruzzi, H., \& Turkenburg, W. C. (2009). Largescale bioenergy production from soybeans and switchgrass in Argentina. Part A. Potential and economic feasibility for national and international markets. Renewable and Sustainable Energy Reviews, 13, 1710-1733.

Donato, L. B., Huerga I. R., \& Hilbert J. A. (2008). Balance Energético de la producción de biodiesel a partir de soja en la República Argentina. INTA, N ${ }^{\circ}$ Doc IIR-BC-INF08-08.

Douglas, J. (1988). Conceptual design of chemical processes. Mcgraw-Hill.

Dunnett, A., Adjiman C. S., \& Shah, N. (2008). A spatially explicit whole-system model of the lignocellulosic bioethanol supply chain: An assessment of decentralised processing potential. Biotechnology for Biofuels. Available from: http://www.biotechnologyforbiofuels.com/content/1/1/13.

Energy Market (2010). Available from www.e-energymarket.com/news as Argentina's biodiesel growth, 29-04-10.

Falasca, S., \& Ulberich, A. (2008). Potencialidad bioenergética sudamericana a partir de forestaciones con Jatropha sp. (J. curcas, hieronymi y macrocarpa). Revista Virtual de Redesma, 102-115.

Font, F. (2003). Las Especies del Género Jatropha L. (Euphorbiaceae, Crotonoideae) en Argentina. Revista del Círculo de Coleccionistas de Cactus y Crasas de la República Argentina (Vol. 2, no. 1).

Guillen-Gosálbez, G., \& Grossmann, I. (2010). A global optimization strategy for the environmentally conscious design of chemical supply chains under uncertainty in the damage assessment model. Computers E' Chemical Engineering, 34(1), 42-58.

Guillén-Gosálbez, G., Mele, F., \& Grossmann, I. E. (2010). A bi-criterion optimization approach for the design and planning of hydrogen supply chains for vehicle use. AIChE Journal, 56(3), 650-667.

Guillén-Gosálbez, G., Mele, F., \& Grossmann, I. E. (2009). Optimal design and planning of sustainable chemical supply chains under uncertainty. AICHE Journal, 55, 99-121.

Ibañez, C. (2008). Hidrovía del Paraná y el comercio granario. Available from www.minagri.gob.ar.

Iermanó, M. J., \& Sarandón, S. J. (2009). Is it sustainable the production of biofuels in large scale? The case of biodiesel in Argentina. Revista Brasileira de Agroecologia, 4(1), 4-17.

Karuppiah, R., Peschel, A., Martín, M., Grossmann, I. E., Martinson, W., \& Zullo, L. (2008). Energy optimization for the design of corn-based ethanol plants. AIChE Journal, 54, 1499-1525.

Kostin, A., Guillén-Gosálbez, G., Mele, F., Bagajewicz, M., \& Jiménez, L. (2010). Integrating pricing policies in the strategic planning of supply chains: A case study of the sugar cane industry in Argentina. Computer Aided Chemical Engineering, 28, 103-108.

Lamers, P. (2006). Emerging liquid biofuel markets. Environmental Management and Policy Master of Science Thesis. Sweden.

Lamers, P., McCormick, K., \& Hilbert, J. A. (2008). The emerging liquid biofuel market in Argentina: Implications for domestic demand and international trade. Energy Policy, 36, 1479-1490.

Mele, F., Kostin, A. M., Guillén-Gosálbez, G., \& Jiménez, L. (2010). Multi-objective model for more sustainable fuel supply chains. A case study of the sugarcane industry in Argentina. AIChE Journal, 650-657.

Molina, C. (2007). Biocombustibles: Una oportunidad para el agro, una oportunidad para Argentina. OSDE Foundation Dissertation. 20-11-07, Rosario, Santa Fé, Argentina.

Molina, C. (2010a). Argentina es el principal exportador mundial de biodiesel. Available from http://www.lu17.com/a/59294e3e-bdb6-11df-932d-000000000000.

Molina, C. (2010b). Argentina podría duplicar su corte de $5 \%$ al $10 \%$ de Biocarburantes. Available from www.biodieselspain.com/2010/04/19.

Molina, C. (2010c). En 2015 la industria del biodiesel podría abastecer al mercado interno con un corte del $20 \%$. Available from www.biodiesel.com.ar/tag/aabh.

Papageorgiou, L. G., Rotstein, G. E., \& Shah, N. (2001). Strategic supply chain optimization for the pharmaceutical industries. Industrial \& Engineering Chemistry Research, 40, 275-286.

Pengue, W. (2005). Transgenic crops in Argentina: The ecological and social debt. Bulletin of Science, Technology and Society, 25, 314-322.

PNEG1412 (2006). INTA Project. Available from www1.inta.gov.ar/proyectos2006.

Rozemberg, R., Saslavsky, D., \& Svarzman, G. (2009) La industria de biocombustibles en Argentina, Chapter 2 in La industria de biocombustibles en el MERCOSUR(Ed. López, A.). ISBN: 978-9974-7992-7-1

SAGPyA (2010). Programa Nacional de Biocombustibles, Dirección Nacional de Producción Agropecuaria y Forestal, Ministerio de Economía y Producción, Argentina. www.sagpya.gov.ar.

SAGPyA (2006). Secretaría de Agricultura, Ganadería. Pesca y Alimentos, Argentina. Available from www.sagpya.mecon.gov.ar.

Schulz, E. P., Diaz, M. S., \& Bandoni, J. A. (2005). Supply chain optimization of large scale continuous processes. Computers $\mathcal{E}$ ' Chemical Engineering, 29, 1305-1316.

Shah, N. (2005). Process industry supply chains: Advances and challenges. Computers E' Chemical Engineering, 29, 1225-1235.

Shapiro, J. F. (2001). Modeling the supply chain. Duxbury Press.

Shapiro, J. F. (2004). Challenges of strategic supply chain planning and modeling. Computers \& Chemical Engineering, 28, 855-861.

Slade, R., Bauen, A., \& Shah, N. (2009). The commercial performance of cellulosic ethanol supply-chains in Europe, Biotechnology for Biofuels. Available from www.biotechnologyforbiofuels.com/content/2/1/3.

World Oil Magazine (2010). Available from www.worldoil.com. 
You, F., \& Grossmann, I. E. (2007). In Papageorgiou, \& Georgiadis (Eds.), Optimal design and operational planning of responsive process supply chains; book chapter in process system engineering: Vol. 3. Supply chain optimization. Weinheim: Wiley$\mathrm{VCH}$.

You, F., \& Grossmann, I. E. (2010). Integrated multi-echelon supply chain design with inventories under uncertainty: MINLP models, computational strategies. AIChE Journal, 56, 419-440.
Zamboni, A., Bezzo, F., \& Shah, N. (2009a). Spatially explicit static model for the strategic design of future bioethanol production systems. 1. Cost minimization. Energy E' Fuels, 23, 5121-5133.

Zamboni, A., Bezzo, F. \& Shah, N. (2009b). Spatially explicit static model for the strategic design of future bioethanol production systems. 2. Multi-objective environmental optimization. Energy \& Fuels, 23, 5134-5143. 